\title{
Intersected Ruralities: "Campeiro" Youth and Narratives of Self and Other in Social Media*
}

\author{
Miriam Adelman** \\ César Bueno Franco*** \\ Andressa Fontana Pires****
}

\begin{abstract}
This article presents current research on gender and identity among youth who take part in the campeiro cultural circuit in the Curitiba metropolitan area. We look specifically at the narratives that these youth formulate through use of social media, focusing on how they represent masculinity and femininity, sexuality and the body, consumption, cultural identities and leisure interests. Based on a study of young men and women and their Facebook profiles, linked to a broader project of ethnographic research, we argue that social media facilitate their participation in wider fields of discourse circulation, offering an opportunity and perhaps even encouraging them to express themselves in ways that partially disrupt conventional "traditionalist" patterns and ideals.
\end{abstract}

Key Words: "Campeira" Culture, Youth, New Ruralities, Gender, Social Media, Gaucho Traditionalism.

* Received February 18, 2015, approved April 16, 2015. Translated by Miriam Adelman. Reviewed by Richard Miskolci. The authors extend their thanks to Tiemi Kayamori Lobato da Costa, Gabriela Becker, Leandro Lechacoski and Camila Mariane de Souza, interlocutors whose ideas and assistance were fundamental during several stages of this research. Grants from CAPES and $\mathrm{CNPq}$ were also essential to the project; most importantly, the support received through the CNPQ/SPM program 32/2012, "Women, Gender and Feminism".

** Professor of Sociology, UFPR, Curitiba, PR, Brasil. Currently linked to the Postgraduate Programs in Sociology and Literary Studies. miriamad2008.gmail.com

${ }^{* * * *}$ Holds a Master's Degree in Sociology from the UFPR, Curitiba, PR, Brasil. csarbf@gmail.com

***** Undergraduate Degree in Social Sciences, UFPR, Curitiba, PR, Brasil. andressafonti@gmail.com 


\section{Introduction}

Over the last few decades, the social sciences have been faced with the challenge of re-evaluating concepts and developing approaches more sensitive to the new elements of a globalized, post-modern social reality that in many significant ways no longer corresponds to the world that classical theories described. One of the major targets of theoretical and methodological critique has been the legacy of binary concepts and structures of thought: the enlightenment tradition that saw the world in terms of pairs and polar opposites, such as subject/object, reason/emotion and male/female. As post-structuralist criticism has so indefatigably argued, the relationship between elements taken to be opposites has always implied hierarchy, indicating positions of superiority/subordination. Other binomies of this type that have dominated modern social thought include "the West and the rest" (Hall, 2003), rural/urban, heterossexual/homossexual, "white"/"black", human/non-human, culture/nature and modernity/tradition.

The deconstructive legacy of post-structuralist thought initiating with Derrida and Foucault, infused with the postcolonialist critique that takes off with Edward Said and further transformed through the philosophical contributions of queer feminist Judith Butler - inaugurated changes in the field of the social sciences that were deep and comprehensive enough to leave no field of inquiry intact. Today we work with a relationallogic that seeks the fissures, fluidity, complex interconnections and vanishing points of power relations and domination; dichotomous pairs are not only seen as objects to be theoretically deconstructed but also practices in which subaltern positions become sites of struggle. In this context, our objects of study will always demand a methodological approach that can capture complexity, that carries its own set of risks - how to meet the challenge of nuance, instability, intersectionality? - and promises more than a few surprises along the way. 


\section{Milieu and media}

Some five years ago, when we began our first incursions into the world of traditionalist rodeo (Adelman and Becker, 2013; Adelman and Lechacoski, 2013), we could not have imagined the complexity of so much we would find there. The variety and hybridity in the way rodeo fans and participants constructed their identities, the intensity of rural/urban flux, the dense translations of "traditional" and "modern" were both formidable and fascinating research challenges.

Our work began with inquiry into young women's participation in rodeo competition, drawing some parallels with earlier work we had done on women athletes (amateurs and professionals) in other equestrian sports and fueled by the knowledge that this southern Brazilian rodeo milieu had only recently opened its doors to female competitors. ${ }^{1}$ According to our own field research, the opening had required cautious negotiating on the part of women riders and got off the ground during the second half of the 1990s (Adelman and Becker, 2013). Beginning our study a scant decade after this sea change meant a unique opportunity to study the dynamics of gender interactions and cultural vicissitudes. Another feature that attracted us to the milieu was the way in which it seemed to bring people from different backgrounds together - urban middle class professionals as well as enthusiasts and participants from rural and urban working class environments.

After spending several years carrying out ethnographic work that included frequent visits to local rodeos as well as hanging out at certain barns (the "native category" is "cabanha" ${ }^{2}$ ), we turned

\footnotetext{
1 We refer here specifically to the rodeos organized through the circuit belonging to the Gaucho Traditionalist Movement (MTG) and mediated through local centers (CTGs).

2 The term "cabanha" is used in the campeiro milieu to refer to a place that is simultaneously boarding and training stable and a more general site for gathering together and promoting Traditionalist leisure activities (barbecues, dances, informal rodeo training, etc).
} 
our attention to a specific focus on the young people who frequent the milieu (Pires, 2014). This was when we realized that by looking at their use of a social network ${ }^{3}$, we could access the ways in which participants represent their identities and express their subjectivities, as well as data on issues such as patterns of cultural consumption and religious and political beliefs. The fact that we had carried out intense ethnographic work made extending our research to mediated interactions relatively easy. Many informants had already requested our Facebook "friendship", thus providing contact to their wider social circle as well. Furthermore, our initial access to the Facebook pages of people who were part of the campeira online community expanded once our visual sociology project - documentary photography of daily life at barns, rodeos and community rides - took off. Not long after posting some of our photos on Facebook pages, "friends" of these "friends" requested our "friendship", an opportunity we seized in the interests of ethnographic work and online community participation.

On the other hand, bringing social networks into "the field" also introduces new difficulties. Within sociology and other related disciplines, the meanings and effects of internet and social network use are now amply debated. Back in the early days of the internet, Turkle (1997) had acute foresight into the changes that would soon come about:

\begin{abstract}
A system of networks in rapid expansion, collectively referred to as Internet, connects millions of people in new spaces that are about to change the way in which we think, the nature of our sexuality, the organization of our communities and even our identity (Turkle, 1997:11, our translation).
\end{abstract}

3 However intuitive the matter may be, let us clarify here what we mean by digital media: the means of communication that in our times depend on electronic equipment connected through the web, thereby including connection and the physical material that makes it possible (Miskolci, 2011). 
From the start, the effects that a worldwide computer network could have on people's lives were imaginable: people were no longer "solid figures living in defined territories, but nomadic distributions moving through a space in flux" (Levy, 2011:139, our translation). As time went by and the internet became increasingly popular and dynamic, other issues came to the forefront: questions regarding the key elements of contemporary web culture, whether seen as alienating or democratizing, as forces that encourage new forms of sociability that move on and off-line or as new obstacles to face to face interaction. Today these issues are all over the media, widely debated on the very digital media they attempt to assess. Scholars and researchers the world over struggle to understand the course and the nuances of subjectivity, sociability and the identity and discursive constructions of the contemporary world. Thus, although it is all too easy to follow the path of typically negative views on the use of digital media, seen as an extension of larger scale ideological and technological manipulation (Postman, 1994) or to defend the notion of the digital revolution as an open door to profound and utopian social and moral change (Levy, 2011), many studies reinforce the idea of digital media as a complex and valuable resource from which any number of effects can spring. Thus, from studies of the so called "virtual communities" (Franco, 2015; Rheingold, 1996), to the more specific interactional platforms (Zago, 2013; Aspling, 2011; Turkle, 1997) and broader theoretical studies that are sensitive complexities of the terrain, we find exemplary works that avoid the pitfalls of over generalizing diagnostics (Baym, 2013; Lemos, 2010). In this regard, bringing social media into "the field" means opening our analysis up to a series of new challenges. Furthermore, it involves the recognition that in the experience and daily life of young people today, social network use is largely taken for granted, as if they had "always been there" for everyone. This way of thinking about the internet and its options becomes in turn a part of the way they are used, and another challenge that researchers must deal with. 
For our present purposes, we consider social networks as tools that "anyone" who has regular access to the internet whether via computer or mobile phone - can use to elaborate a "narrative of the self" read or seen by others; in this regard, they can be seen as "democratizing" means and instruments of reflexivity. ${ }^{4}$ At the same time, we see how they can become new ways of engaging in symbolic struggles and negotiations, including those that revolve around the construction of social status. Thus, they become new instruments for the "presentation of self in everyday life" (Goffmann, 1985), appropriated by people who often have an anxiety-driven interest in representing themselves as persons whose lives can be envied - regardless of whatever trials and tribulations they face in everyday off line life. Perhaps this can be seen as the old preoccupation of social critic Christopher Lasch (1978) - writing almost two decades before the internet's mass appearance - about a "culture of narcissism", coming back with a vengeance. Yet, as social critics who are less pessimistic about our current reality argue, the opportunities that these media provide to people who were previously excluded from as visible participants in processes of social communication and the "culture industry" should not be overlooked. At their best, they may stimulate new forms of social participation and stimulate reflection on problems that are both individual and collective, encouraging diverse forms of pro-active behavior that include social activism. However, digital media may also serve to propitiate anxieties regarding the social norms and hegemonic values that prevail both on and offline. These possibilities and actually observable tendencies are a concern for all researchers whose work focuses on or includes digital media use.

4 Reflexivity has become a key concept in contemporary sociology, largely through Anthony Giddens' work (1991). Indian anthropologist Arjun Appadurai (1996:7) has extended this argument to include the diverse realities of countries "outside the center" where, he argues, people incorporate the modern and postmodern challenges of self-imagining into their lives, processes that can be associated specifically with digital media and the way they have become available around the world. 


\section{Social networks in a youth culture}

Our ethnographic work on rodeos organized by CTGs in the state of Paraná and, in a broader sense, the popular equestrian culture of the region, sent us right from conventional fieldwork mingling with people offline - into online space. It was a spontaneous process in which young people were especially prominent, and through which we were once more able to confirm the magnetic power that discourses and practices associated with "campeiro tradition" hold over many youth today. Furthermore, we observed that these youth were actively involved in resignification processes, and could be seen as representatives of a generation protagonizing the changing meanings of being "traditionalist".

The Gaucho Traditionalist Movement (MTG) is one the most visible and outspoken representatives of the vida campeira ${ }^{5}$ in southern Brazil. In recent decades, it has also spread to other regions of the country, and even to other parts of the world (Oliven, 2006). Originally established as a meeting ground for a group of men interested in safeguarding a rural past that they feared was disappearing within the specific context of the state of Rio Grande do Sul, ${ }^{6}$ MTG founding members and their followers later discovered the importance of bringing "their women" (wives, daughters, other relatives and community members) in, as the movement also made its way north and permitted local adaptations in other states (Sopelsa, 2005). Nonetheless, the ideas behind the movement continued to attribute clearly demarcated social roles to men and women, known as "peões" (peons) and "prendas" (literally, "gifts" - in the sense of something precious that is given or exchanged), respectively. Nonetheless, late 20th

5 Country life or lifestyle; the Portuguese connotes a rurality that is associated with rural workers and peasants as much or more than with rural elites.

6 Following Sedgwick (1985) and her discussion of how modern public spaces become a locus of male sociability, which includes anlysis of the symbolic and material positions attributed to women within them. 
century changes affected this "traditionalist" culture in ways that were similar to the new winds stirring in other walks and spheres of social life, and by the late 1990s - some forty years after the movement got off the ground - the earlier traditionalist notion of "prenda" was challenged, mostly just because many women, both the young and the not so young decided it was about time they were allowed their rightful position within traditionalist equestrian culture, given longstanding historical connections between rural women and horses, and the contemporary leisure riding practices that came to reinforce them (Adelman and Becker, 2013).

Riding and other campeira activities have a broad appeal for many youth, male and female, who live in rural and semi-rural areas, as well as among city dwellers who have rural connections (family, relatives, friends) A space for leisure and socializing, we noted that as the young people we observed and spoke to get involved in these activities, they make a considerable emotional investment in them, which have as correlates a lot of time and money spent in and on them. Being campeiro becomes a (post) modern life style and source of pride, linked to particular discourses that value rural environments and large animals and often flaunt romanticized notions of nature and rural roots. Today this has also come to mean a certain "unisex" enjoyment of sport and the out of doors, not to be belittled. While this does not mean that gender is actually "deconstructed" or ceases to act as a fundamental symbolic or practical organizing principle, in some crucial ways it shows that gender relations are being re-negotiated; as we will attempt to show, this also applies within the realm of social network use, where "cultural hybridization" is also manifested. Class, race/ethnicity, gender, generation, and sexuality are elements that fuse, combine and interact within global and local contexts, producing identities that are at the same time consolidated and fluid, significant and shifting. As Hall has argued, the subject belongs to a world of fragments which $\mathrm{s} / \mathrm{he}$ pieces together to make sense out of life and to create particular meanings; what $\mathrm{s} /$ he produces as identity, or as identification, is often composed of conflicting or even contradictory elements (Hall, 
1992:12). The internet and its expanding social networks become one of the most significant vehicles for cultural hybridization, providing access to local and global elements that become the building blocks of individual and collective notions of self and being.

In the universe we studied, elements of urban (post)modern discourse are often at work "behind the scenes", while up at the forefront narratives of traditionalism and campeira culture are binding forces that bring people from rural and urban, middle and popular class backgrounds together. The youth that we look at here build strong connections with others that revolve around "being campeiro" and extend in a variety of terrains of daily life: work, study, sport, leisure and dating. And, as we have emphasized above, this has also meant that a once masculine sphere of practice opens its doors to girls and women. Girls, in particular, use social network pages to express themselves according to new notions of "prenda" that include sexual subjecthood. They also go on at length about their relationships with their equine partners, whom they often refer to as "best friends", faithful partners and/or vehicles for their own existential freedom - in this sense, echoing experiences noted in other studies and literature (Pierson, 2001; Adelman and Knijnik, 2013). For the boys and young men, there is a clear legacy to fit into, part of a well-disseminated social imaginary that places virile men atop horses, whether the heroic South American gaucho or the cowboy whose image is repeated in global medias and in this case, have clear Hollywood origins.

Nonetheless, some young men show a new willingness to resignify masculinity, which we see as arising primarily from the inclusion of women in a milieu that was previously extremely homosocial. As we shall soon see, they express admiration for the girls and women who ride and the courage and competence that qualifies them as "brutas" - a native category which we might translate as, in this case, as "rough rider", but which in other contexts would be pejorative, more along the lines of the literal "brute". Other indications of change can be found in the new ways 
in which some boys and youth refer to homosexuality, once the exclusive terrain of joking and ridicule, and now sometimes provoking more inquisitive and respectful commentaries that foreground rights and acceptance of "diversity". These are issues that take up space on the pages of Facebook, the social network tool that is most popular today in Brazil and worldwide, and in which the youth we have studied make themselves part of both local and global communities, as they go about building their online profiles and narratives of self.

\section{The study: methodology and findings}

The first methodological challenge that we faced when we began to put together a research design for digital media was the selection of informants. The large catalogue of possibilities initially offered through Facebook was in itself daunting, Having initial access to a large selection of profiles, we decided on two basic criteria: the first, an obvious consequence of our goals, was to choose a young person, male or female, significantly identified with "campeiro" culture; the second, our informants had to have a certain minimum of online activity.

This was complicated by the fact that some of the youth whose profiles we wanted to follow posted only occasionally posting and then not appearing again for several days particularly those living in rural and semi-rural areas. As Miskolci (2011) reminds us, internet access and use in Brazil is still unequally distributed, favoring those who are not only young but also urban, middle class and better educated; our target population was, in this sense, a group somewhat "outside the norm". Furthermore, since we had decided to conduct a pilot study based on a two-week Facebook profile observation period, regular use became an absolute prerequisite in selecting our informants (a filter which, in future studies, might be dealt with differently). In addition to these criteria, we decided to limit ourselves to youth from a particular part of the Greater Curitiba region - Campina Grande do Sul, São José dos Pinhais, which in 
addition to their central urban areas include an expanse of rural and semi-rural territory where popular Brazilian equestrian culture and horse sports thrive. This criteria was also a largely spontaneous result of our own involvement offline, as researchers in or near these communities, and demonstrates, once again, the offline-online continuities of everyday life. Furthermore, an online "snowball sampling" technique was also spontaneously obtained: when a young person, male or female, became a part of our sample, we acquired immediate access to his or her network of friends; among them, we invariably found a large number of other youth with similar "campeiro" interests, residing in the same or nearby communities of the Greater Curitiba.

Developing a research design using Facebook profiles also meant taking this social network's specific characteristics into account. Each digital media has particularities that signify potential and/or limitations, and in this case, one of Facebook's outstanding features is its focus on what is happening at the moment, encouraging people to post and make constant reference to the here and now, which persists as headline until the next "here and now" takes over. From a researcher's point of view, the flow of "here and nows" can be seen as a movement in meanings and discourse, over (usually short) periods of time - this was how we attempted to relate to the "campeiro" youth profiles we were following.

Over the 15 day period we observed the profiles we had selected, these "Facebook friends" were unaware that we were studying them, a strategy that we followed in order not to upset the spontaneity of their social network use. Thus, as researchers, we became a typical case of lurkers (Braga, 2008; Amaral, 2010), a posture that digital media such as Facebook make possible, insofar as information is shared with a broad public and in which anonymous browsing is the rule. It also meant working only with 
the material appearing on profile pages, rather than through direct contact with "informants".

Prior to our observations, we had given considerable thought to the way images are used online and how people negotiate forms of self-presentation, issues that - as stated above are longstanding sociological concerns that come together in unique ways within contemporary digital media. We followed an intuitive and ethnographic path suggested by experienced researchers of the field (Pascoe, 2012): keeping up our own profiles, adding people, accepting friend requests, observing posts, and trying to understand them as narrative and discursive forms. For our specific analytic purposes here, we selected a total of 13 profiles of campeiro youth -6 young men and 7 young women who met the criteria explained above. Although we were not completely comfortable with our status as "lurkers", our analytic efforts were restricted to a most careful interpretation of forms of self-presentation and identity, based on materials with the youth themselves make available on line.

In an effort to systematize our analysis, we broke each profile down into a series of observable elements: cover photos (large and set into the background, in which landscapes or panoramic images are common) and profile photos (in a smaller, lower left corner inset, most often a portrait that clearly displays facial features.)We also took note of the "likes" that each profile garnered, which, apparently no more than a mere "click of the mouse", can be seen as relevant signs of identification. We separated "likes" into four categories: campeiro, religious, political and "other". Finally, we examined the content of the material that each profile shared on its "timeline" - the page that provides an overview of a person's

7 Earlier research plans included setting up a Facebook group where topics could be discussed. These plans were abandoned for a number of practical reasons. It is also important to state that, as off-line researchers with involvement in the campeiro community, not all of the profiles belonged to "strangers". However, during this stage of online research, all profiles were studied for the data they provided on FB pages, and other information coming from outside sources was not taken into consideration. 
entire Facebook history. We noticed that posts were made up of several keys elements - images (photos or other), videos, texts and hashtags ${ }^{8}$ - which separately or together conveyed meanings and messages (for example, a photo related to a campeira practice or activity, a text that goes along with a photo or a hashtag that reinforces an idea or concept.)

Thus, Facebook has functional specificities that characterize the way it works as an interactional platform, allowing people to manipulate their online image (Baym, 2013) through what and how much they show of themselves (Pascoe, 2011) while reinforcing the idea that a particular "self" can be publicly sustained (Miller, 1995). Youth who post images of horses, song lyrics, who "like" this or that profile (which may even refer to the profile of a product, a band or a popular saying) are not only expressing their own tastes but exploring new discursivities and narratives of self.

These youth relate to one another through a wide range of elements and cultural discourses. Observing their "likes" on pages of their interest - pages which generate numerous "likes", in the dozens, hundreds or thousands - their identification with "campeira" culture co-exists comfortably alongside other cultural signs which have very little to do with it. Thus, we see they also "like" designer name brands for imported clothing, electronic equipment and Hollywood films, and wide range of musical genres $^{9}$ - rock, pop, reggae, Brazilian "pagode" and even electronic music, while specifically "campeira" genres ("sertanejo", "nativista" and "gaucho") did not occupy significant space on their timelines. During the period we followed their profiles, none of the youth in our sample published campeira or gaucho traditionalist

8 Textual resources marked with the \# sign preceding a word or phrase. In Facebook, they work as keywords, so that if one clicks on the hashtag \#summer, other recent posts containing the same hashtag will appear. Yet they also use to create or reinforce meanings, as in this example, \#summer, in which the season "summer", in itself or connected to other elements, signifies.

9 Keeping in mind that within this context, the "like" is not simply a taste or preference, but the public manifestation of a taste or preference, through deliberate on line publicizing. 
music directly on their timelines, showing preference for pop or Brazilian "pagode". The young women limited their references to traditionalist music through particular verses, which they sometimes copied as titles for the photos that they posted of themselves with their horses or in other situations that emphasized their participation in the campeiro milieu.

Thus, these young people once again provide us with illustrative examples of why and how, rather than using closed and dichotomizing notions of cultural consumption, the latter should be understood as fluid and hybrid. Through the "likes" we observed on their interest pages, we were able to identify ways in which they put different worlds together, intensifying the possibilities for cultural dialogue that the digital universe itself encourages. It is also important to note the absence of posts that were expressly political or engaging in direct social critique of any form.

Nonetheless, it would be premature to take this as a sign that "campeiro" youth are apolitical or less interested in politics than other young Brazilians. In fact, narratives of self on Facebook seem to encourage certain forms of positioning onself in relation to themes of everyday or social life, more often than political engagement per sé, and this is certainly the case for the "campeiros". Certainly, there is much more to be researched as far as these youth and their political beliefs are concerned; we could be expect a wide variety of positions rather than any clear homogeneity.

What we were able to detect were their "likes" on the profile pages of politicians - who were, curiously, all local, such as the mayors of the towns they live in - and on other profiles that have openly political connotations or ramifications. The "interest" page for the political slogan "The South is my country" ["O sul é meu país"] garners some "likes", which is not surprising since this ideological banner, separatist and right wing in nature, has historical links to Gaucho traditionalism as a cultural movement (Becker, 2011; Oliven, 2006). That it reappears here in a contemporary digital media is evidence of the way in which new media can be mobilized to perpetuate or recycle "old" political 
ideologies; how they do so - undergoing what kinds of hybridization or resignification - is also a question that merits further research. Another viewpoint that was expressed was someone's "like" on an interest page against the prohibition of rodeos. This is an issue that has mobilized "campeiro" and gaucho traditionalist movement protest, since it involves and impacts directly on their lifestyle - on sport, leisure, business and personal interests - and places them in a tense relationship with animal rights activists, in particular. ${ }^{10}$

In the wake of these new, hybrid cultural forms, the youth we are studying bring us back to the issue of resignification - of how experiences are examined in the light of information and ideas about those practices, rendering new meanings and underdoing constitutive changes (Giddens, 1990). Internet and social networks intensify these processes. In the case in point, we see how digital media provide a space for different "campeiro" experiences to come together, shared by people from rural and urban environments in a way that is proper to our contemporary moment and certainly facilitated by the "inclusive" aspects of new communications technologies. Thus, for young participants, the "campeiro" life style is not exclusively rural, although it is certainly not "urban". Rather, life styles, subjectivities and practices connect these elements through more fluid patterns. As young "campeiro" participants from the city redeem a real or fantasized familial connection to rural life, youth from the countryside find their own rural roots acquire greater value and respect, while also able to claim as their own elements of a youth culture that spring from urban settings. Nonetheless, caution must be taken here insofar as increased cultural exchange requires many other social and

\footnotetext{
${ }^{10}$ This is an interesting issue for sociologists of social and cultural movements, as well as for the sociology of animals. In relation to this latter point, we see very different positions taken by groups who see themselves as, on the one hand, spokespersons for a "subaltern" group (non-human animals) unable to defend themselves, and on the other, people who see themselves as profoundly linked to non-human animals (cattle, horses) on a day-to-day basis, and who defend their own modes of knowledge and relationship to the latter.
} 
institutional changes if it is to truly ameliorate social inequality or promote deeper de-construction of societal hierarchies, material and symbolic.

Among the young people whose profiles we analyzed, the use of "campeiro" motifs for profile and cover photos is absolutely commonplace. This seems to suggest that these youth are highly invested in asserting themselves as members of that particular milieu. In fact, in the majority of cases, both of these two central images are "campeiras" - on horseback, and/or taking part in rodeo competitions or other equestrian or "traditionalist" activities. Another way of demonstrating identification and association with this milieu is through dress. Photos abound in which the youth male and female - are decked out in full "campeiro" or "gaucho" attire, for which there is a particular Brazilian term: pilchados. ${ }^{11}$ Considering Facebook as an important site in which users claim and perform identities, use of "campeiro" attire therein, and particularly on cover or profile images, can be considered to be an important cultural statement. Nonetheless, this way of dressing, which may perhaps be taken as the key marker of "campeiro" identity, may also mingle with other styles or markers. Young people engage in a daily manipulation of signs, which includes ambiguous compositions, appearing in some images in traditionalist outfits, and in others, in designer jeans, perhaps purchased on a trip to the mall and exhibited with the same pride as one's riding boots. Furthermore, images are presented and negotiated on a daily or almost daily basis through the most up-todate communications technologies, and transmitted through a broad social network in which "campeiro" events and experiences

\footnotetext{
11 That is, wearing the outfit adopted by the Traditionalist movement, in itself a reappropriation/resignification of pampas culture, translated, as it were, for a post-modern context in which there is a wide market for traditionalist goods, including the bombacha pants which are slightly differentiated for men and women, tee or polo shirt, cowboy-style hat and boots, belt (especially for men) and neck kerchief (used by men and women).
} 
might figure as just another one of the plethora of eccentricities nostalgically evoking life styles bound to a "simpler" past. ${ }^{12}$

A young man, for example, posts a big photo to his profile showing his participation in the "18th Interstate Criollo Rodeo", which he then uses to create continuity between that event and his Facebook life. The fault lines separating the urban and the "traditional", as well as online/offline, are blurred. Similarly, the use of the "selfie" has been completely incorporated into practices of "campeiro" identity construction. We observe selfies that young women have taken of themselves in rodeo attire, and to do away with any shadow of doubt as to where it was taken, the phrase "rodeio \#diferenciado" [rodeo special] appears alongside it. Facebook becomes the medium through which campeiro events, activities and commercial products are showcased and presented: a postmodern medium through which they activate tropes of tradition and rurality, albeit infused - as we have indicated above - with other cultural elements, fashions and tropes that they are attracted to. The hybrid prevails, even if, from time to time, nostalgic elements and fantasies of "simpler" times may be evoked; such nostalgia is however, less present among the young than among members of the older traditionalist generations studied elsewhere (Becker, 2011; Oliven, 2006).

Another fundamental issue plays itself out within the hybrid identity dynamics of these young people. Through the language that is used here in constructing online sociability, the idea of "belonging" looms large. That is, going beyond the explicit references to campeiro cultural products and discourses, particular types of slang, "in jokes" and in group figures of speech were constantly appearing. They were often accompanied by hashtags (a typographic sign that is followed by words or short phrases that are mean to locate events or ideas in the quickest and clearest way that is possible) which situated an a thing or an occurrence spatially and in reference to a particular network of social relations.

\footnotetext{
${ }^{12}$ In fact, the notion of "simpler times" is a frequent trope of campeiro and traditionalist imaginaries.
} 
Examples such as \#tavabaodemais, \#rodeio, \#peleiando, \#cadinho, \#pinhão, \#querência, etc. made reference to shared moments - festivals, rodeo competition aor training and rides, among others.

Thus, the possibility of "speaking about" a particular experience took on particular linguistic patterns, meant to reinforce the specificity of group to those outside it, although equally capable of communicating the existence of that group experience to others. In fact, the use of hashtags, which has become quite common in digital media today, fulfills expressive and explanatory functions, and shows here how youth who take part in "campeiro" or traditionalist activities may be somewhat or very well versed in new technological languages which they appropriate, mixing new resources with traditionalist terminology. A hashtag may evoke a sensation or feeling or even explain a post (where it was taken, in which context), adding more layers of meaning to a communication. For example, we observe two young ladies who have taken a selfie together at a local rodeo, their smiling face and posture suggesting they are thoroughly enjoying themselves, accompanied by an ironic hashtag: \#reallybored ("\#chateadas".) Thus, it is important to note that hashtags are typical Facebook tools; "campeiro" youth use them creatively in another demonstration of how new technological instruments become instruments for speaking about "the traditional".

Furthermore, this technological language can serve as a resource that alleviates certain limitations or problems. For example, the habit of posting ready-made messages - in particular, images with inlaid text - may reflect a combination of convenience and communicative difficulties. The person who posts a readymade text is freed from the task of personal expression, which not everyone who uses the site is interested in doing or able to do with ease. The appeal that images hold can also be understood in this light (Baym, 2013). These messages also enable those who use them to a more implicit way of exposing needs, interests, opinions or desires. This is the case of motivational messages, in which it is suggested that the person who posts has a particular need for that 
type of motivation, yet some degree of protective ambiguity is maintained.

\section{Representing gender}

Among those aspects of identity and subjectivity that campeiro youth use their Facebook pages to express are those related to gender, to constructions of masculinity and femininity. One of the most evident ways this is manifested is in clothing and dress, important markers of gender. Although the basic pilcha campeiro (explained above) is almost unisex, online constructions of image include other forms of attire (jeans and other types of sportswear are the most common. Attire is more modest and less varied in the case of the young men, while young women here as in most other walks of life- seem much more eager and invested in using dress to create an image of body and self.

Issues of gender and sexuality come to the forefront through written text as well. Expectations and anxieties related to gender and sexuality surfaced on a number of occasions. One notable case was that of a young man who posted the following message:

I am always happy, and you wanna know why? Because I don't expect anything from anybody. Expecting things hurts. Problems don't go on forever, they can always be solved. The only thing that can't be is death. Life is short, so, love it!

A friend, another campeiro youth, then in apparent jest accused him of being gay, probably due to the intimate nature of the message. The one who had initially posted responded in a joking tone of provocation - "Ai machão..." ["Hey big macho"] to which both followed with a response "rrss", indicating risos, that is, laughter - a rough equivalent to the English LOL. From our perspective, this type of exchange represents a form of heteronormative policing, or at least an expression of anxiety which hides behind laughter and joking; it is a playful sort of homosociality under the watchful eyes of a compulsory 
heterosexuality that appears quite frequently among campeiro youth interacting through digital media.

Homosociality, in the sense of male camaraderie, is a recurrent marker of gendered spaces and attitudes in the campeiro milieu in general, and reflected in our online study as well. One young man posted a photo and text in which he expressed his gratitude to a companion (parceiro; literally, partner) of several years; the person who had received the tribute modestly answered reiterating that "he was who he was" and thanking his friend for the camaraderie. Thus, we see that rural/campeira forms of male bonding find new ways of expressing themselves in (post) modern digital terms, using photos and emphasizing the trope of companionship that is so much a part of offline expression: "parceria". Expressions of mutual admiration of this type are not uncommon, and the term parceiro itself is constantly employed for men referring to other men. Another young man posted a photo in which he is standing next to another guy at the rodeo, followed by the phrase "Here there is real parceria!" The importance of this "native category" - parceria/parceiro [partnership/partner] within the campeiro universe, and particularly within between-men dynamics seems to suggest that the label may function as release from the ever-present specter of male homosexuality (Sedgwick, 1985). Parceiro connotes strength and reliability, but within a tranquilizing normative sense in which the boundaries of heterosexuality are (supposedly) protected by the concept itself.

Nonetheless, rather than affirming that all young campeiro men in our sample are completely given to compulsory heterosexuality, ambiguities surface here, as elsewhere. At best, youth are beginning to learn to live with diversity. One young man's post made direct reference to gender, sexuality and prejudice in an image-text (a ready-made post that he copied to his timeline), as follows:

If you're gay, it's a sin. If you're bisexual, you're confused. If you are very thin, it's because you're a junkie. If you're fat, you eat too much. If you dress well, you're rich and spoiled. 
If you dress sloppily, you're a slum dweller. If you say what you think, you're rude. If you don't say what you think, you're false. If you cry, you're overly dramatic. If she has a lot of male friends, she's a slut. If he has a lot of female friends, he's a fag. Will we ever live in a world without labels? (our emphasis).

When general remarks on behavior take on this vague critical tone, they enable youth to express reflections on gender that are not so unlike what they communicate through the images of self that they produce intentionally; the indirect nature of the comments may also reflect the caution that young campeiro men seem to take regarding too much self-exposure. Yet there are other, albeit timid gestures that seem to suggest some relaxing or transgressing gender norms, such as the stylish haircuts that some of the young men use, indicating aesthetic preoccupations. More than once, we've seen photos of young men who take off their cowboy hats to reveal highlights in their dark hair; one youth proudly posted his aesthetic zeal to his timeline, "Going for a new look!" [Dando um tapa no visu!!!]. The phrase was followed by the English language name of the barber shop, suggesting the place qualified as "chique", rather than an ordinary, run - of - the - mill corner joint.

The young women's profiles show similar degrees of reflexivity. One young lady posted a selfie followed by the message: "If you're not happy when you're single, you won't be happy when you have a boyfriend either. Happiness comes from inside yourself, not from a [having a] man" ${ }^{13}$ The critique of the cultural logic of romantic love/heterossexual coupledom running through her personal defense of her singlehood is not to be scoffed it. ${ }^{14}$ Yet at the same time, since this message is set inside a self-

\footnotetext{
13 "Se não for feliz solteira, também não vai ser namorando. A felicidade vem do interior, não de um homem".

${ }^{14}$ A critique that should not be belittled, especially if we take into consideration that one of the major contradictions of the "post-feminist" culture and discourse
} 
portrait, it may also have a sort of hidden agenda, exemplifying strategically calculated forms of self-exposure through a social network, such as the getting out the message that this young lady is, in fact, free for dating and going out with men. One way or another, it is consistent with our findings of female forms of selfexpression emphasizing subjecthood.

If we take the historical characteristics of the rodeo milieu, of rural Brazilian equestrian culture and of homosocial environments in general into consideration, the youth we are looking at here actively demonstrate that they are accessing new, emergent patterns of gender relations. Young women seem unafraid to take positions, through what they post and what they "like", that place them in tension or even in frank opposition to traditional (and "traditionalist") notions of proper female behavior. They actively re-signify the traditionalist notion of the prenda (explained earlier) and present themselves as protagonists of their sexual lives and interests, further shown through the way a number of them shared interest pages like "Proud to be single" (Solteira com orgulho) and "Yes, single!" (Solteira sim). Another impressive example was a young woman who posted a video in which she sings her own version of a popular song. Accompanied by a boy who plays the guitar, she substitutes lyrics that make derogatory reference to a "gold digging" woman ("mulher interesseira") for a message that makes fun of a "sexually absent man". Her version is full of current popular slang about sexual practices and preferences, placing women center stage as subjects and spokeswomen of desire: "that's the way we like it" ("é assim que nois gosta").

Young men also try out some possibilities for resignifying gender, whether by critiquing stereotypes, relativizing the type of "care of self" that men can engage in, or rethinking how they represent women. A post of this sort showed a young man with a toddler - perhaps his own daughter - dressed in campeira attire and accompanied by the hashtags \#vaiserdomeio $e$

adopted by hegemonic media is the way in which it simultaneously accepts and abjectifies single women (Taylor, 2012). 
\#essavaiserbruta - "[she's] gonna be one of us", "she's gonna be a rough rider" - the later phrase both funny and subversive, insofar as the term "bruto", also discussed above, conventionally connotes rural, cowboy or "campeiro" masculinity.

Nonetheless, gendered distinctions continue to be a fundamental category used to organize experience, exalting, for example, the good looks of (expected of ) campeiro women, in clear reproduction and reinforcement of generalized social and cultural notions of feminine beauty. Likes on interest pages devoted to "the most beautiful [female] calf ropers" "ropers who use perfume"15 ["As prendinhas mais lindas do laço perfumado paranaenseLaço perfumado], which were also "liked" by the young women whose profiles we followed in our research, suggest that vanity continues to be seen one of the supreme markers of femininity, fervently embraced in an environment where other markers are subverted or re-cast

\section{Conclusions: a very (post) modern traditionalism}

"Youth" is a social and sociological category that enables us to link notions of generation and life cycle to other relational categories, such as rural/urban, classe social, raça/etnicidade, sexualidade e gênero. To speak of "campeira" youth is no different: it brings singular experiences together with "an historical and cultural condition that [does not] unfold in the same way for all those it includes" (Marguilis apud Pereira, 2010:1). Different styles, sociabilities and cultural preferences abound within the group we study, and use of digital media become a way of expressing and constructing them. While some young people divide their time between a wider range of activities, others are more unilaterally devoted to campeiro practices; for some, campeiro practices are their work (as is the case for young men working at barns), for others it is leisure, and still others is the most important aspect of

\footnotetext{
15 "As prendinhas mais lindas do laço perfumado paranaense", "O laço perfumado!"
} 
life which, beginning earlier in life as a hobby or sporting practice, may later become livelihood or profession (such as a career in veterinary medicine). ${ }^{16}$

It is also worthy to note that, insofar as all campeiro youth whose profiles we accompanied also emphasized the sporting character of rodeo, they participate not only in youth culture but in what sport sociologists understand as contemporary tendencies to draw practices and activities linked to other dimensions of life into the realm of modern, competitive sport. ${ }^{17}$ Thus, as one of the youth in our sample exemplified, using a profile photo of himself in the arena, on horseback, accompanied by the phrase "How I suffer when it's over! Roping competition is my life. Class-A sport!", frequent references of this type seem meant to place the sport firmly within what Maguire has referred to as the (very postmodern) global sport media complex (1999), in which different industries and markets (including digital media) come together. Many of the interest "likes" of the youth whose profiles we examined are directed toward pages that reinforce traditionalist rodeo roping practice as a sport and legitimate its practitioners as athletes; ways of referring to their sport - their "Class A sport" suggest there may be some rivalry going on in relation to other sporting practices, most of which are less ambiguous in their relationship to modern urban life.

Another example of the youthful eclecticism and flexibility of the group we studied and warranting further exploration can be found in appropriations of religious references. Facebook manifestations of faith are not infrequent, commonly using the Traditionalist movement trope which can be considered a takeoff

\footnotetext{
${ }^{16}$ While some boys from working or popular class backgrounds begin to work with around the barn and with horses early on, we saw no girls involved in similar practices. For the later, building a career or a livelihood in the horse world seems to depend upon institutional (post-secondary) forms of training and education.

${ }^{17}$ In this case, we are dealing with practices that originate in cattle ranching and associated labor, which have been re-organized and regulated according to CTG rules - a perfect example of the sportization processes discussed by Elias and Dunning (1992).
} 
on the notion of "Our father in the heavens" ["nosso patrão do céu"], which plays with the fact that local traditionalist organizations are headed by (an almost always) male figure referred to not as director or president but as "patrão" (literally, the "boss", simulating the language that "peons" - cowboys, cattle hands - would be to refer to their employer or overseer) .Other religious manifestations include young people who use Facebook tools to "like" interest pages like one which reveres the figure of the virgin, "Nossa Senhora, cuida de mim" (literally, Our mother, protect me") or "Campeiros for Christ". Playful and hybrid as they sometimes are, we observed no references to religions outside the conventional sphere of current Brazilian Catholicism or Protestantism.

In sum, Facebook use is a fundamental part of current processes of the circulation of cultural discourses, and one in which each user is being constantly incited to elaborate a narrative of the self, through text and image, negotiating and managing selfpresentation according to the expectations of a global culture, site of both homogenizing and difference-sustaining forces and of symbolic and material struggles that are not refractory to local dimensions or to the expression of specific group or "subcultural" imaginaries. Campeiro youth are part of a complex cultural and political scenario. Their ideas and practices represent conflicts, contradictions and movements that go beyond the simple "conservatism" that critics of the Traditionalist movement suggested in the $1990 \mathrm{~s}^{18}$ and in many ways, they are not unlike other youth of their generation (Weller, 2005; Pereira, 2010; Pires, 2014), living out the challenges of a very difficult world. This also means they belong to a generation in which new approaches are being taken and developed, bringing questions of gender, race/ethnicity, sexual diversity, and the preservation of material

\footnotetext{
18 See Becker (2013) for a summary of the intense debates regarding the political ideologies linked to the Traditionalist Movement (MTG). These were raging debates of the 1990s, and there is no reason to assume that the issues and positions continue to be exactly as they were then, some twenty years ago.
} 
and cultural heritage, biodiversity and the environment to the forefront of public and political debate.

Gender issues and the revalorization of the rural are elements of this scenario that are particular relevant to the lives and interests of campeiro youth, given their participation in a practice of rural heritage that draws popular and middle class, urban and rural groups into new types of relationships, as well as the imposing fact that girls' and women's sporting participation coincides, timewise, with the dissemination of internet and digital media. Our online research is but an initial moment in a new phase of an ongoing project, from which a number of significant clues can be taken, such as the possible erosion of compulsory heterosexuality and the emergence of new meanings and ways of being women. Social network observation and study provides a wide window through which the desires, experiences and conflicts of Brazilian young people can be captured and examined, in a world in which both expectations and uncertainties are on the rise.

\section{Bibliography}

ADELMAN, Miriam. "As prendas também vestem bombacha!" Mulheres, homens e novas configurações de gênero no mundo do rodeio paranaense. In: DA LUZ, Nanci Stancki Casagrande; LINDAMIR, Salete. (Orgs.) Entrelaçando gênero e diversidade: múltiplos olhares. Curitiba, Editora da UTFPR. No prelo.

ADELMAN Miriam and LECHACOSKI, Leandro. Qui est prenda, qui est peao ? Renégocier des corporéités et des subjectivités dans le rodéo du Sud du Brésil. In: Ayral, S. and Raibaud, Y. (Orgs.) Pour en finir avec la fabrique des garçons. Vol 2: Loisirs, sport, culture. Bordeaux, éditions MSHA, 2014, pp.147-158.

ADELMAN, Miriam and KNIJNIK, Jorge. Introduction - women, men and horses: looking at the equestrian world through a gender lens. In: ADELMAN, $\mathrm{M}$ and KNIJNIK, J. Gender in equestrian sport: riding around the world. Dordrecht/Heidelberg/New York/London, Springer, 2013, pp.1-14. 
cadernos pagu (44) Miriam Adelman, César B. Franco, Andressa F. Pires 167

ADELMAN, Miriam and BECKER, Gabriela. Tradition and transgression: women who ride the rodeo in southern Brazil. In: ADELMAN, M and KNIJNIK, J. Gender in equestrian sport: riding around the world. Dordrecht/Heidelberg/New York/London, Springer, 2013, pp.73-90.

AmARAL, Adriana. Etnografia e pesquisa em cibercultura: limites e insuficiências metodológicas. Revista USP. São Paulo, 2010, nº 86, pp.122-135

[http://www.revistas.usp.br/revusp/article/download/13818/15636 acesso maio 2013].

APPADURAI, Arjun. Modernity at Large: Cultural Dimensions of Globalization. Minneapolis/London, University of Minnesota Press, 1996.

ASPLING, Fredrik. The private and the public in online presentations of the self: a critical development of Goffman's dramaturgical perspective. Dissertação de Mestrado, Sociology, Stockholms Universitet, 2011.

BARBERO, Jesús Martín. Jóvenes: comunicación e identidade. Revista Digital de la OEI Pensar Iberoamérica, vol. 0, 2002, pp.7-14 [http://www. comisionporlamemoria.org/investigacionyense\%C3\%B1anza/pdf bibli oteca/Barbero.pdf - acesso maio 2014].

BAYM, Nancy K. Personal connections in the digital age. Malden, Polity Press, 2013.

BECKER, Gabriela. Prendas e peões num mundo em transição? A participação feminina nas práticas equestres do laço comprido. Monografia de graduação, Ciências Sociais, UFPR, 2013.

BOUDREAU, Kelly; DiXON, Shanly. Playing with social network sites: actual \& ideal selves. Selected Paper of Internet Research 14.0. Denver, 2013 [http://spir.aoir.org/index.php/spir/article/viewFile/696/291- acesso jan. 2015].

BRAGA, Adriana. Personas materno-eletrônicas: feminilidade e interação no blog Mothern. Porto Alegre, Sulina, 2008.

ELIAS, Norbert and DUNNING, Eric. Quest for Excitement: Sport and Leisure in the Civilizing Process. London, Blackwell Publishers, 1992. 
FACIOLI, Lara Roberta Rodrigues. Conectadas - Uma análise de práticas de ajuda-múta feminina na era das mídias digitais. Dissertação de Mestrado, Sociologia, Universidade Federal de São Carlos, 2013.

FRANCO, César B. "Como conquistar mulheres?" - Masculinidade e subjetivação em uma comunidade virtual. Dissertação de Mestrado, Sociologia, UFPR, 2015.

GidDEnS, Anthony. As Consequências da Modernidade. São Paulo, Unesp, 1991.

Goffman, Erving. A Representação do Eu na Vida Cotidiana. Petrópolis, Editora Vozes, 1985.

HAll, Stuart. Da Diáspora: Identidades e Mediações Culturais. Belo Horizonte, Editora UFMG/Humanitas, 2003.

. A Identidade Cultural na Pós-Modernidade. Rio de Janeiro, DP\&A, 2001.

LASCH, Christopher. The Culture of Narcissism: American Life in an Age of Diminishing Expectations. New York, Warner Books, 1979.

LEMOS, Andre. Cibercultura: tecnologia e vida social na cultura contemporânea. Porto Alegre, Ed. Sulina, 2010.

LEVY, Pierre. A inteligência coletiva: por uma antropologia do ciberespaço. São Paulo, Loyola, 2011.

MAGUIRE, Joseph. Global Sport: Identities, Societies, Civilizations. London/New York, Polity Press, 1999.

MILLER, Hugh. The presentation of self in electronic life: Goffman on the internet. Paper presented at Embodied Knowledge and Virtual Space conference. University of London, 1985 [http://www.douri.sh/classes/ics234cw04/miller2.pdf - acesso jan. 2015].

MISKOLCI, Richard. Novas conexões: notas teórico-metodológicas para pesquisas sobre o uso de mídias digitais. Cronos, Revista da PósGraduação em Ciências Sociais, UFRN, Natal, vol. 12, nº 2, jul./dez., 2011, pp.9-22. 
cadernos pagu (44) Miriam Adelman, César B. Franco, Andressa F. Pires 169

PASCOE, C. J. Studying young people's new media use: methodological shifts and educational innovations. Theory into practice, vol. 51, abr. 2012, pp.76-82.

. Resource and risk: youth sexuality and new media use. Sexuality, Research and Social Policy, vol. 8, mar. 2011, pp.5-17.

PEREIRA, Alexandre B. Muitas Palavras: a discussão recente sobre juventude nas Ciências Sociais, 2010 [http://nau.fflch.usp.br/sites/nau.fflch.usp.br/files/upload/paginas/Artigo -Alexandre-Barbosa-Pereira.pdf - acesso abril 2014].

Pierson, Melissa H. Dark Horses and Black Beauties: Animals, Women, a Passion . New York, W.W. Norton \& Company, 2001.

PIRES, André. Ruralidades em Transformação: Agricultores, Caseiros e Moradores de Condomínio. São Paulo, Annablume, 2007.

PIRES, Andressa F. Tradição e juventude: uma investigação sociológica sobre as dinâmicas da identidade gaúcha. Monografia de Graduação, Ciências Sociais, UFPR, 2014.

POSTMAn, Neil. Tecnopólio: a rendição da cultura à tecnologia. São Paulo, Nobel, 1994.

RHEINGOLD, Howard. A comunidade virtual. Lisboa, Gradiva, 1996.

SAID, Edward. Orientalism. Londres, Penguin Books, 1977.

SEDGWICK, Kosofsky Eve. Between Men: English Literature and Male Homosocial Desire. New York, Columbia University Press, 1985.

SOPELSA, Renata. Aquerenciados em um novo rincão: migrantes e o culto às tradições gaúchas na cidade de Ponta Grossa, PR, 19581968. Dissertação de Mestrado, História, UFPR, 2005.

TAYLOR, Anthea. Single Women in Popular Culture: the Limits of Postfeminism. New York, Palgrave/Macmillan, 2012.

TURKLE, Sherry. A vida no ecrã - a identidade na era da internet. Lisboa, Relógio D'Água Editores, 1997.

WeLlER, Wivian. A presença feminina nas (sub)culturas juvenis: a arte de se tornar visível. Revista Estudos Feministas, Florianópolis, vol.13, ${ }^{\circ}$ 1, jan./abr., 2005, pp.107-126. 
170 Intersected Ruralities

ZAGO, Luís Felipe. Os meninos - corpo, gênero e sexualidade através de um site de relacionamentos. Tese de Doutorado, Educação, UFRGS, 2013. 